\title{
WASTAFEL INJEKTUR SEBAGAI SOLUSI CUCI TANGAN DI TEMPAT UMUM UNTUK MEMBANTU PENCEGAHAN VIRUS CORONA DI KOTA GORONTALO
}

\section{Injecture Beware As A Public Handwashing Solution To Help Prevention Of Corona Viruses In The City Of Gorontalo}

\author{
Yunita Djamalu' ${ }^{1)}$, Siradjuddin Haluti' ${ }^{2)}$, Burhan Liputo ${ }^{3)}$ \\ ${ }^{1,2}$ Program Studi Mesin dan Peralatan Pertanian, Politeknik Gorontalo \\ Email: naura@poligon.ac.id ${ }^{1)}$
}

\begin{abstract}
ABSTRAK
Corona Virus Disease 19 (Covid19) atau lebih dikenal dengan sebutan virus Corona merupakan virus yang menyerang sistem pernapasan dan bisa mengakibatkan kematian. Bahkan organisasi kesehatan dunia, WHO, menghimbau seluruh dunia untuk mengutamakan perilaku hidup sehat dan pembiasaan mencuci tangan. Di Indonesia, pencegahan penyebaran virus ini mulai disosialisaikan di masyarakat terutama di tempat-tempat umum seperti tempat ibadah, sekolah-sekolah, pasar ataupun di suatu instansi, untuk itu pada pengabdian masyarakat yang akan dilakukan oleh tim Dosen dan Teknisi dari Prodi Mesin dan Peralatan Pertanian Politeknik Gorontalo, sosialisasi tindakan preventif tersebut akan dilaksanakan untuk membantu pemerintah dalam menyediakan tempat cuci tangan berupa wastafel injektur yang aman untuk beberapa tempat umum di Kota Gorontalo
\end{abstract}

Kata Kunci : Covid19; Wastafel Injektur; Prototype; Cuci Tangan; Kota Gorontalo

\begin{abstract}
Corona Virus Disease 19 (Covid19) or better known as the Corona virus is a virus that attacks the respiratory system and can cause death. Even the world health organization, WHO, urges the whole world to prioritize healthy living habits and hand washing habits. In Indonesia, the prevention of the spread of this virus has begun to be disseminated in the community, especially in public places such as places of worship, schools, markets or in an agency, for this reason community service will be carried out by a team of lecturers and technicians from the Agricultural Machinery and Equipment Study Program. Gorontalo Polytechnic, the socialization of preventive measures will be carried out to assist the government in providing a place for washing hands in the form of a safe injector sink for several public places in Gorontalo City.
\end{abstract}

Keywords: Covid19; Injector Lavatory; Prototype; Hand Wash; Gorontalo City

\section{PENDAHULUAN}

Penyakit korona virus 2019 atau coronavirus disease 2019, disingkat VIRUS CORONA adalah penyakit menular yang disebabkan oleh SARS-CoV-2, salah satu jenis koronavirus. Penyakit ini mengakibatkan pandemik koronavirus 2019-2020 termasuk di Indonesia. Penderita VIRUS CORONA dapat mengalami 
demam, batuk kering, dan kesulitan bernapas. Sakit tenggorokan, pilek, atau bersin-bersin lebih jarang ditemukan Pada penderita yang paling rentan, penyakit ini dapat berujung pada pneumonia dan kegagalan multiorgan.

Infeksi menyebar dari satu orang ke orang lain yakni melalui percikan (droplet) dari saluran pernapasan yang sering dihasilkan saat batuk atau bersin. Waktu dari paparan virus hingga timbulnya gejala klinis berkisar antara 1-14 hari dengan rata-rata 5 hari. Untuk itu pemerintah indonesia khususnya pemerintah provinsi gorontalo selalu menyerukan beberapa tips untuk pencegahan virus corona.

Menurut kemenkes dan gugus tugas virus corona di Provinsi Gorontalo Penyakit korona virus sampai pada tanggal 20 April 2020 sudah terdapat 4 kasus positif virus corona di Provinsi Gorontalo
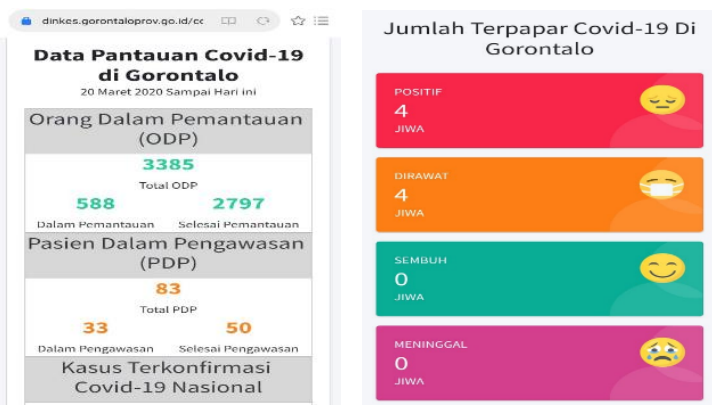

Gambar 1. Data Penyebaran Virus Corona di Kota Gorontalo

Sumber: Dinkes.gorontaloprov,2020

Adapun himbauan pemerintah Provinsi Gorontalo dalam pencegahan virus corona ini adalah:

1. Seringlah mencuci tangan Anda dengan air bersih mengalir dan sabun, atau cairan antiseptik berbahan dasar alkohol. Mengapa? Mencuci tangan dengan air bersih yang mengalir dan sabun, atau cairan antiseptik berbahan dasar alkohol dapat membunuh virus di tangan Anda.

2. Jaga jarak setidaknya 1 meter dengan orang yang batuk-batuk atau bersinbersin. Mengapa? Ketika batuk atau bersin, orang mengeluarkan percikan dari hidung atau mulutnya dan percikan ini dapat membawa virus. jika anda terlalu dekat, anda dapat menghirup percikan ini dan juga virus virus corona jika orang yang batuk itu terjangkit penyakit ini.

3. hindari menyentuh mata, hidung, dan mulut. mengapa? tangan menyentuh berbagai permukaan benda dan virus penyakit ini dapat tertempel di tangan. tangan yang terkontaminasi dapat membawa virus ini ke mata, hidung atau mulut, yang dapat menjadi titik masuk virus ini ke tubuh anda sehingga anda menjadi sakit.

4. pastikan anda dan orang-orang di sekitar anda mengikuti etika batuk dan bersin dengan cara menutup mulut dan hidung dengan siku terlipat atau tisu saat batuk atau bersin dan segera buang tisu bekas tersebut. mengapa? percikan dapat menyebarkan virus. dengan mengikuti etika batuk dan bersin, anda melindungi orang-orang di sekitar dari virus-virus seperti batuk pilek, flu dan virus corona.

5. tetaplah tinggal di rumah jika merasa kurang sehat. jika anda demam, batuk dan kesulitan bernapas, segeralah cari pertolongan medis dan tetap memberitahukan kondisi anda terlebih dahulu. ikuti arahan dinas kesehatan setempat anda. mengapa? kementerian kesehatan dan dinas kesehatan daerah akan memiliki informasi terbaru tentang situasi di wilayah anda. dengan memberitahukan kondisi anda terlebih dahulu, petugas kesehatan yang akan merawat anda dapat segera mengarahkan anda ke fasilitas pelayanan kesehatan yang tepat. langkah ini juga melindungi anda dan membantu mencegah penyebaran virus dan infeksi lainnya.

6. tetap ikuti informasi terbaru tentang hotspot-hotspot virus corona (kota atau daerah di mana virus corona menyebar luas). jika memungkinkan, hindari bepergian ke tempat-tempat tersebut terutama jika anda sudah berusia lanjut atau mengidap diabetes, sakit jantung atau paru-paru mengapa? kemungkinan 
tertular virus corona lebih tinggi di tempat-tempat tersebut.

Permasalahan Mitra

Adapun permasalahan yang akan dibahas dalam tulisan ini yakni bagaimana cara penggunaan wastafel injektur dan dimana lokasi penempatan wastafel injektor ditempat umum yang ada di Kota Gorontalo, yang akan dibagikan oleh tim pengabdian masyarakat Prodi Mesin dan Peralatan Pertanian Politeknik Gorontalo. Desain alat PkM dapat dilihat pada gambar 2.

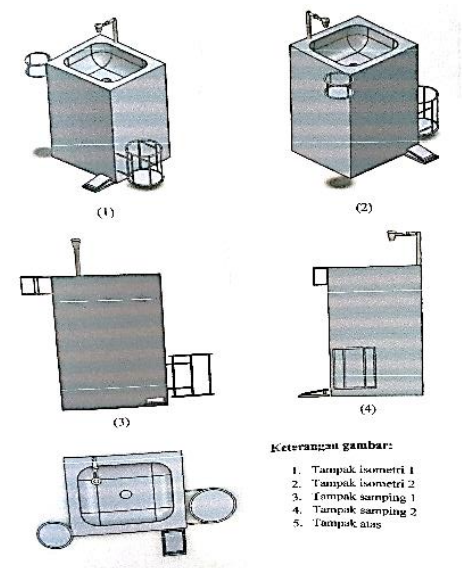

Gambar 2. Desain Alat Wastafel Injektur

\section{METODE PELAKSANAAN KEGIATAN}

Metode yang akan dilaksanakan merupakan sebuah rangkaian tahapan yang disusun secara sistematis, berikut adalah gambaran flow map yang akan berjalan :
Tujuan Kegiatan Adapun tujuan dari penulisan ini adalah berkontribusi terhadap penyelesaian pandemik covid-19 di Provinsi Gorontalo khususnya di Kota Gorontalo.

\section{SOLUSI DAN TARGET LUARAN}

Ada beberapa usaha yang dapat dilakukan sebagai solusi dari permaslaahan tersebut yakni:

\section{Solusi Permasalahan}

1. Membantu pemerintah provinsi gorontalo dalam menyelesaikan dan menanggulangi penyebaran virus corona di provinsi gorontalo khususnya di daerah kota gorontalo

2. Membantu masyarakat khususnya yang sering berkunjung ke tempat-tempat umum menyediakan tempat cuci tangan yang aman

3. Melaksanakan pengabdian masyarakat sebagai salah satu tri dharma perguruan tinggi yang harus dilakukan oleh setiap dosen disetiap semester.

Luaran dan Target Capaian

1. Prototype wastafel injektur untuk tempat umum di Kota Gorontalo

2. Artikel ilmiah yang dimuat pada Jurnal Abdimas Gorontalo (JAG)

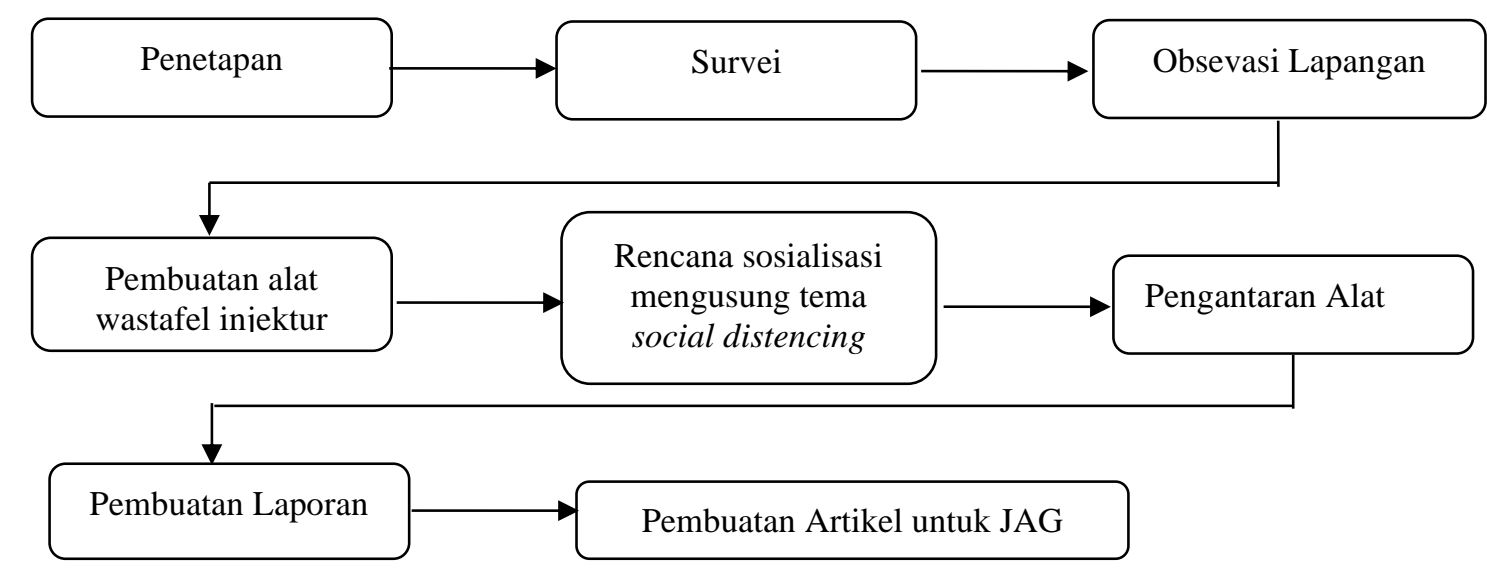

Gambar 3. Bagan Alir Pelaksanaan PkM 


\section{KESIMPULAN DAN SARAN}

Kesimpulan

Kesimpulan dari pelaksanaan pada kegiatan PkM sebagai berikut:

1. Dihasilkan alat berupa wastafel injektur yang dapat membantu upaya pemerintah dalam menanggulangi penyebaran Covid19.

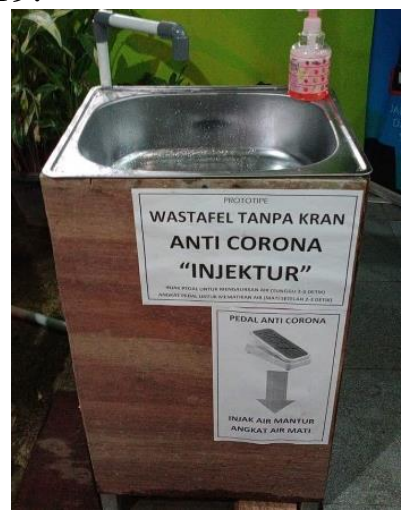

Gambar 4. Alat Wastafel Injektur

2. Jumlah peserta dibatasi 5 orang untuk menghindari kerumunan masa yakni terdiri dari 2 orang dari pemerintah desa dan 3 orang tim PkM

3. Tim Pengabdi menyampaikan tata cara penggunaan alat, memasang spanduk dan memposisikan alat sesuai arahan pemerintah desa.

4. Alat wastafel injektur ini sangat dibutuhkan selain untuk membantu pemerintah gorontalo juga sangat membantu masyarakat yang berada dikeramaian sebagai solusi cuci tangan agar terhindar dari virus korona.

Saran

Pada akhir kegiatan PkM, pemerintah desa dan masyarakat disekitar lokasi penempatan wastafel konjektur di Kota Gorontalo mengharapkan ada lagi kegiatan pengabdian yang serupa sebagai solusi ditengah pandemik covid 19.

\section{DAFTAR PUSTAKA}

Antu, SE \& Djamalu Y. (2018). Desain Mesin pencacah sampah organic rumah tangga untuk pembuatan pupuk kompos. JTPG Vol 3.No 2. Oktober 2018 Hal (57-65)

https://dinkes.gorontaloprov.go.id/virus corona/20-04-2020 